\title{
Feminization of poverty program on female breadwinners in East Java, Indonesia
}

\section{Program feminisasi kemiskinan pada perempuan pencari nafkah di Jawa Timur, Indonesia}

\author{
Doddy Sumbodo Singgih ${ }^{\bowtie}$, Sudarso, Siti Mas'udah \\ Department of Sociology, Faculty of Social and Political Sciences, Universitas Airlangga, \\ Indonesia \\ Surabaya, 60286, East Java Province, Indonesia \\ E-mail of corresponding author: doddy.singgih@ fisip.unair.ac.id
}

\begin{abstract}
This article describes the feminization of poverty-reducing program by directing the program to female breadwinners in 10 regencies in East Java Province, Indonesia. The main activity of such program is to provide productive financial support to a target group, namely poor female breadwinners in rural areas. The main focus of the research is to examine the targeting accuracy of the program in providing productive financial support to the target group. To acquire this objective, a survey was conducted to collect data for the examination. In addition, the targeting accuracy is measured for the accuracy of its recipients, its amount, and its utilization. The results of the study indicate that the feminization of poverty-reducing program has met the target. It means that the funds have really been given to the poor female breadwinners who live in rural areas. The sum of the money has been in agreement with the amount that should be given, and it has been utilized by the target group productively in accordance with the program objectives.
\end{abstract}

Keywords: feminization of poverty program, poverty; female; rural; sociology

\begin{abstract}
Abstrak
Artikel ini menjelaskan program feminisasi untuk mengurangi kemiskinan pada pencari nafkah perempuan di 10 kabupaten di Provinsi Jawa Timur, Indonesia. Penelitian dilakukan dengan menerapkan metode survei. Kegiatan utama dari program ini adalah untuk memberikan dukungan keuangan produktif untuk kelompok sasaran, yaitu perempuan miskin pencari nafkah di daerah pedesaan. Fokus utama dari penelitian ini adalah untuk memeriksa akurasi penargetan dari program dalam memberikan dukungan keuangan produktif untuk kelompok sasaran. Akurasi penargetan diukur untuk keakuratan penerimanya, jumlah, dan pemanfaatannya. Hasil penelitian menunjukkan bahwa program pengurangan kemiskinan telah memenuhi target. Ini berarti bahwa dana tersebut telah diberikan kepada para perempuan miskin pencari nafkah yang tinggal di daerah pedesaan. Jumlah uang yang telah sesuai dengan jumlah yang harus diberikan, dan telah dimanfaatkan oleh kelompok sasaran produktif menurut tujuan program.
\end{abstract}

Kata kunci: program feminisasi kemiskinan, kemiskinan; perempuan; pedesaan; sosiologi

\section{Introduction}

Up to now, in developing countries there have been many programs aimed to reduce poverty (Chibba 2008; Perdana \& Maxwell 2004; Ariyani 2015; Ashiomanedu 2008; Domfeh \& Bawole 2009; Fosu 2017; Cobbinah et al. 2013; Singgih et al 2020). However, there are only few poverty reduction programs specifically targeted to poor female breadwinners. Such programs have never been carried out before. Owing to that concern, this article describes the results of a research on a poverty reduction program for female breadwinners in one of the provinces in Indonesia, namely East Java Province.

Although East Java is a province that contributes a large economy, but there are still residents of East Java who are in line with the poverty line (Zamhari et al. 2015; Mahsunah 2013). Poverty in East Java includes poor households and informal sectors (Tain 2011). In East Java Province, to prevent the continuity of feminization program toward poverty on female breadwinners in rural areas or a process where poverty in rural areas related to the subordinate status of women as breadwinners, starting from 
the year 2014 to the present, a project called Jalan Lain Menuju Mandiri dan Sejahtera (Jalin Matra) or Other Way Towards Independent and Prosperous Feminization of Poverty Reduction program has been established. The project is an integral part of the other three Jalin Matra programs set up by the East Java provincial government from the year 2014 up to present. This program is specifically targeting poor female breadwinners in the rural areas. The Jalin Matra program is implemented to improve the effectiveness of poverty alleviation and improve the economy of the people of East Java (Mufidah 2018; Husna 2018; Kurniawan 2018; Zarkasi 2015; Nurmawati \& Soseco 2017).

Substantially, Feminization of Poverty Reduction program is not only aimed for short-term objective but also for long-term objective, i.e. the anticipation that female breadwinners are getting poorer. In the year 2010-2013, the poverty reduction program in East Java Province was named Jalan Lain Menuju Kesejahteraan Rakyat (Jalin Kesra) or Other Way Toward People Prosperity. The program was specifically aimed to Extremely Poor Households or Rumah Tangga yang Sangat Miskin (RTSM) based on the poverty indicators used in Indonesia.This RTSM group should have obtained priority from the government so that they could survive. The results from previous studies indicated that the program had been successful in carrying out its mission against poverty in East Java province, especially the poverty experienced by RTSM or those who were in decile 1 on the structure of poverty in East Java Province. A research conducted by the team of the Institute for Research and Community Service Universitas Airlangga (Singgih \& Sudarso 2013) on the evaluation of Jalin Kesra, RTSM assistance program implementation East Java Province had precisely met the target since the program complied with the expected goals.

The following is the results of a number of respondents who had been interviewed. Half number of respondents said that the provision of Jalin Kesra had met its requirements (52.73\%). Many respondents said that the program had been in conformity with the promise given by the government (74.55\%). Many respondents also said that it had been in line with the economic activity $(75.45 \%)$; it had been in agreement with the potential of the human resources (78\%); it had been in compliance with the environmental conditions (79.09\%); and it had been in accordance with the poverty experienced $(70 \%)$. Although the targeting accuracy of the program has not yet reached the "ideal level" as expected, at least it has helped RTSM in East Java Province to survive. From the study, it is also noted that $100 \%$ or all of the RSTM respondents expected that such assistance program for poverty reduction be continued in the subsequent years, even though it is given in various forms, such as, the provision of productive employment, the provision of small business capital, and the provision of cattle.

Today, the success of Jalin Kesra program has been continued by another program, namely Jalan Lain Menuju Mandiri dan Sejahtera (Jalin Matra) or Other Way Towards Independent and Prosperous. As stated in the Regional Medium-Term Development Plan (Rencana Pembangunan Jangka Menengah Daerah) of East Java Province year 2014-2019, the East Java Provincial Government will keep supporting the poor (pro-poor). Thus, it becomes the East Java Provincial Government's separate political will to continue the program in the next financial years.

At the beginning of the program, it was planned that Jalin Matra pilot project, as the extremely poor households assistance, would cover 3,309 Kepala Rumah Tangga Perempuan (KRTP) or Female Heads of Households residing in 10 regencies of East Java Province including Banyuwangi, Kediri, Ngawi, Jember, Probolinggo, Pasuruan, Situbondo, Tulungagung, Pamekasan and Bojonegoro. At smaller territorial unit, the pilot project reached 37 districts and 54 villages.

As described in Jalin Matra and based on the data collected by the Central Bureau of Statistics (Badan Pusat Statistik), the regulation of pilot project of Feminization program for reducing poverty in East Java Province year 2014 indicated that the number of East Java residents was more dominated by women. The population census year 2010 showed that the number of the population living East Java Province reached 37.47 million: 18.5 million were men (49.37\%) and 18.97 million were women $(50.63 \%)$. The data were also supported by the released data from the National Team of Poverty Reduction Acceleration or Tim Nasional Percepatan Penanggulangan Kemiskinan (TNP2K) in July 
2012 showing the number of families with women as the household heads with $30 \%$ of welfare status, the lowest throughout Indonesia, reached to 2,864,364 families (KRTP). East Java Province occupied the highest position with the number of 700160 or $24.4 \%$ of KRTP.

Methodologically, as well as any philosophy, the substance, the procedure and the execution of a program will still have the opportunity to be implemented differently from its plan. Therefore, it is neodcessary to carry out academic research activities in the form of Monitoring and Evaluation ( $M$ \& E) on the implementation of the program as early as possible - through both formative or summative evaluation so that the financial support given by the East Java Provincial Government to the Female Heads of Households (KRTP) meets the target.

In the perspective of sociology methodology, monitoring and evaluation are activities which contain two dimensions: first, the field activities are utilized to monitor the process of the implementation of a program; and second, field activities are conducted to evaluate the results of the implementation of a program, both formative and summative. Therefore, $\mathrm{M} \& \mathrm{E}$ do not just fill a list of questions about what and how the implementation of a program but more than that, $\mathrm{M} \& \mathrm{E}$ is a field research activity that uses rigorous methodological procedure to see the reality that really happens in time both expected and unexpected reality.

Therefore, in order to obtain accurate results, monitoring and evaluation activities are commonly performed without notifying the target in advance. In other words, good M \& E are performed in a sudden, without prior notification to the respondents. Real and uncontrived results are methodologically highly expected in $\mathrm{M} \& \mathrm{E}$ method. Moreover, if it is required, $\mathrm{M} \& \mathrm{E}$ can also be used to predict the success and/or the lack of success of the implementation of a development program by identifying a wide range of social, economic and other variables that might be supporting or distracting variables in the implementation of a program.

Through a monitoring and evaluation (M\&E) research, there are two things obtained: first, the monitoring of the process of project implementation; and second, the evaluation of the results of project implementation. Therefore, $M \&$ E research queries five things: the first, how is the targeting accuracy of Jalin Matra; $a$ feminization program for reducing poverty, regarding the accuracy of the recipients, the precision of the amount of the funds given, the accuracy of the place, the time, and the potentials; the second, how is the readiness of KRTP in administering the support provided by Jalin Matra Feminization Program for Reducing Poverty ; the third, how is the construction of KRTP's understanding about the support provided by Jalin Matra feminization program for reducing poverty ; the fourth, how is KRTP's commitment to administer the support provided by Jalin Matra Feminization of Poverty Reduction program; the fifth, what kinds of social and economic constraints are faced and experienced by KRTP in administering the support of Jalin Matra feminization of poverty reduction program.

The goals of a monitoring and evaluation ( $M \&$ E) research activity are: the first, to identify the targeting accuracy of the support given to KRTP by Jalin Matra Feminization Program for Reducing Poverty, particularly regarding the accuracy of the recipients, the precision of the amount of the funds given, the accuracy of the place, the time, and the potentials. The second, to identify the plan for administering the support of Jalin Matra Feminization Program for Reducing Poverty performed by KRTP, primarily concerning to the plan of productive group activities. The third, to identify the social construction of the support for KRTP received from Jalin Matra Feminization Program for Reducing Poverty. The fourth, to identify KRTP's commitment in administering the support provided by Jalin Matra Feminization Program for Reducing Poverty. The fifth, to identify the social and economic constraints faced and experienced by KRTP in administering the support of Jalin Matra Feminization Program for Reducing Poverty.

The expected outcomes of the $M \& E$ research activities are: the first, to examine the targeting accuracy of Jalin Matra Feminization Program for Reducing Poverty. The second, to determine the readiness of KRTP in administering the support provided by Jalin Matra Feminization Program for 
Reducing Poverty. The third, to identify KRTP's construction of the support given by Jalin Matra Feminization Program for Reducing Poverty. The fourth, to determine KRTP's commitment in administering the support provided by Jalin Matra Feminization Program for Reducing Poverty. The fifth, to identify the social and economic constraints faced and experienced by KRTP in administering the support provided by Jalin Matra Feminization Program for Reducing Poverty.

\section{Research Method}

The method used in this monitoring and evaluation $(M \& E)$ research is survey research method with some methodological consideration. The first, this $\mathrm{M} \& \mathrm{E}$ research is conducted to draw an empirical generalization on the success or the lack of success of the program execution. The second, survey research method is commonly used as a research method to make empirical generalization on the reality of the object of the studies.

To obtain a comprehensive picture of the reality studied, the location of the $M \& E$ research covered overall ten regencies in East Java Province, which were set to be the location of Jalin Matra Feminization Program for Reducing Poverty year 2014. The ten regencies were: Pasuruan, Probolinggo, Situbondo, Banyuwangi, Jember, Kediri, Tulungagung, Ngawi, Bojonegoro and Pamekasan.

The target population in this $\mathrm{M} \& \mathrm{E}$ research was female breadwinners residing in the ten regencies. In each regency, approximately ten female breadwinners were selected using purposive sampling, so there were one hundred samples or female bread winners altogether. Such number of samples were also chosen purposively by selecting female breadwinners residing in the district and/or village by name and by address based on the official data published by the East Java Provincial Government.

As released by the East Java Provincial Government in 2014, the number of KRTP or female breadwinners in Pasuruan was 370 KRTP, Probolinggo was 334 KRTP, Situbondo was 287 KRTP, Banyuwangi was 277 KRTP, Jember was 177 KRTP, Kediri was 611 KRTP, Tulungagung was 114 KRTP, Ngawi was 315 KRTP, Bojonegoro was 338 KRTP, and Pamekasan was 486 KRTP. To sum up, there were 3,309 KRTP in total.

Out of the total population, only one hundred KRTP were taken with fair sample distribution, per regency, per district and per village. Since there were still some sampled villages that had not made disbursement of the financial support to KRTP during M \& E data collection, the distribution size of the respondents was changed and thus, it could not be balanced again, as shown in the following data: 1) Pasuruan Regency, Grati District, Rebalas Village, 5 KRTP were taken; 2) Probolinggo Regency, Tongas District, Curahtulis Village, 10 KRTP were taken; 3) Situbondo Regency, Besuki District, Besuki Village, 10 KRTP were taken; 4) Banyuwangi Regency, Tile District, Wetan Village, 25 KRTP were taken; 5) Jember Regency, New Source District, Yosorati Village, 0 KRTP were taken; 6) Kediri Regency, Kepung District, Kepung Village, 16 KRTP were taken; 7) Tulungagung Regency, Ngunut District, Ngunut Village, 0 KRTP were taken; 8) Ngawi Regency, Pangkur District, Babadan Village, 5 KRTP were taken; 9) Bojonegoro Regency, Margomulyo District, Margomulyo Village, 26 KRTP were taken; 10) Pamekasan Regency, Waru District, Bajur Village, 7 KRTP were taken.

The method used for the data collection in this study was structured-interview method and visual observation. The structured-interview used a questionnaire based on the principles of monitoring and evaluation containing variables to measure the process and the results of the implementation of the feminization program for reducing poverty. The variables were the targeting accuracy in distributing the support, the readiness of KRTP in administering the support, KRTP's construction of the meaning of the support, KRTP's commitment in administering the support, and the social and economic constraints in administering the support.

The primary data obtained in this study were directly tabulated and the results of the data tabulation were displayed in the form of frequency tables. These tables were then read and interpreted to address 
issues raised in this $\mathrm{M} \& \mathrm{E}$ study. The tables were read by looking at the percentage of the data in each variable horizontally and comparing it to the upper and the lower categories. Then, the data in the table were compared to the amount of the difference in frequency between the regencies, so that the differences concerning $M \& E$ in inter-regencies appeared significantly.

All data analysis geared to answer five issues proposed at the beginning of the research, are namely: 1) How is the targeting accuracy of Jalin Matra Feminization Program for Reducing Poverty regarding the accuracy of the recipients, the precision of the amount of the funds given, the accuracy of the place, the time, and the potentials?; 2) How is the readiness of KRTP in administering the support provided by Jalin Matra Feminization Program for Reducing Poverty?; 3) How is the construction of KRTP's understanding about the meaning of the support provided by Jalin Matra Feminization Program for Reducing Poverty?; 4) How is KRTP's commitment to administering the support provided by Jalin Matra Feminization Program for Reducing Poverty?; 5) What kinds of social and economic constraints faced and experienced by KRTP in administering the support of Jalin Matra Feminization Program for Reducing Poverty?

\section{Results and Discussion}

In the regulation, it is written that the purpose of feminization program pilot project for reducing poverty reduction is to provide a model activity as a test to measure the effectiveness of the implementation of the program, so that efforts can be prepared to improve the implementation of the program in a larger and wider scale. Meanwhile, Feminization Program for Reducing Poverty is intended to accelerate the speed of poverty reduction with the main target of female breadwinners who earn a very low income. More specifically, this program has several other objectives; first, to provide interaction access and protection of female breadwinners by optimizing the the roles of TP-PKK or Family Welfare Empowerment Movement as a mother care for KRTP ; second, to expand the access of the target group to be productive enterprises in order to increase the economy or the income of the family ; third, to support the social and economic resilience of the target group in order to meet their basic needs ; fourth, to give motivation to the target group in their efforts to increase their welfare ; fifth, to help in fulfilling basic needs through optimalization their potential around their environment.

In India, Goswami \& Majundar (2016) found that there are differences on how women and men perceived poverty based on several aspects. Women define poverty based on land, house type, dependent in family, occupation, and infrastructure to characterize poor household. On the other hand, man characterizing poor household based on sanitation, business, land holding, farming; and occupation as the only common aspect. Employing participatory well-being ranking (PWBR) in 35.000 population of Habra-II Block of West Bengal state, India, this research find different poverty statistics for men and women. Differences are shown in terms of occupation and material possession of households, shows that poverty statistics in women are higher than their male partners.

Women and men experienced poverty in different ways, causes and experiences of poverty are gendered (Bastos et al. 2009; Jackson 1998). Poverty comprises several factors contributing to women's vulnerability to poverty in Portugal during 1995-2001, such as labor market, lone motherhood, aging, and education. Women are not only more prone to high poverty rates than men, but also experience a more severe and intense form of poverty. Based on deprivation analysis, women exposed to higher risk of deprivation. The determinant factor of this condition was labor market participation due to the high rates of gender discrimination that embedded in Portuguese social system.

Research of Tarkowska (2002) stressed on poverty the form if poverty that indicates by increasing amount of family obligations and responsibilities that women bear, which also known as symptoms of the feminization of poverty. Considered as hidden dimension of poverty in Polish woman, this perspective analyzes gender difference in the division of labor, leisure time, and the responsibility of woman to fulfill the basic needs of the family. Particularly in Poland, women take the role as the pillars of poor households by managing family money and applying different strategies to cope with the problem of insufficient incomes. Poverty for women means more obligations with less time. 
Brady \& Kall (2007) concluded that feminization of poverty is still a common phenomenon on affluent Western democratic countries from 1969 to 2000. This study suggests that feminization of poverty are plausibly higher than the previous estimation. Feminization of poverty emerges as distinct social problem, despite its high correlation with men's and overall poverty. Women's, men's, and overall poverty also shares correlation, particularly in welfare state. Applying structural theory to analyze the case, study found that influential factors that contribute to feminization of poverty are social security transfers, single motherhood, sex ratio of the elderly and labor force participation.

The study of female headship, poverty, and vulnerability in Thailand and Vietnam (Klasen et al. 2013) addresses the questions about female headship in households in developing countries regarding the women's consumption, vulnerability to experience shock, probability to suffer from severe shock, and vulnerability to experience poverty compare to male-headed households. This research did not find compelling evidence that female-headed households are worse than the male-headed ones. The significant consideration occurs in heterogeneity of female-headed households. In comparison with male-headed households, female-headed ones are consume more, but tend to be more prone to shock. Different result obtained from Vietnam that only single-headed households are consumption poor and vulnerable to poverty. Different types of female-headed households vary from each other in terms of vulnerability and poverty, except for shock exposure, and it applied in both countries.

Feminization of poverty comprises two negative phenomena, poverty and gender inequality (Mederios \& Costa 2008; Pressman 2003; Pearce 1978). Therefore, priorities in public policies are needed to overwhelm the problem. The study explores the increase in the differences between women and men and between female and male headed households to the feminization of poverty. Focusing in eight countries in Latin America, no evidence of increase in differential poverty between women and men were found. There was an increase of differential poverty among female and male headed households in Mexico and Argentina during the period of observation, but no feminization of poverty occurred in Bolivia, Brazil, Chile, Colombia, Costa Rica, or Venezuela. Yet, this result could not be straightforwardly generalized the phenomena in the whole region.

There has been a growing attention about relations of race and gender in determining social economic status. In Puerto Rico, gender inequality among minority group was relatively small, but evidence of black and Puerto Rican women experience hardship to being women and members of a minority group were found. Using Current Population Survey (CPS 1994-2001), this research estimates the extent to gender variation influences in determining gender differences in poverty rates within and inter-racial ethnic lines. This study consistently found that women are less likely to be poor than men of the same origin, and white women are less likely to be poor than any of the minority-status men. Furthermore, among blacks, Puerto Ricans, Mexicans, and American Indians, the percentage of women with education beyond high school is similar to men. However, the labor participation is not equal, whereas men are likely to employed full time than women. Many black women do not earn sufficient income to escape poverty. Low rates of marriage and high percentage of single parenthood among black women also lead to tendency of poverty.

In East Java, Indonesia as developing country, based on the results of the data analysis and the interpretation of the findings; and based on the primary data obtained from a survey of 104 respondents in 10 regencies, 10 districts and 10 villages, the following conclusions were obtained. Regarding the accuracy of the provision of the support: a total of $93 \%$ of the respondents (KRTP) had received the feminization of poverty reduction support; while the rest, $7 \%$ of the respondents (KRTP) had not received this support; as many as $37 \%$ of the respondents (KRTP) had received cash, $27 \%$ of the respondents had received cattle, $23 \%$ of the respondents had received groceries, and the rest of the respondents had received supports in various forms; $73 \%$ of the respondents (KRTP) had received the feminization of poverty reduction support as much as Rp. 2.500.000,00; whereas, the rest (27\%) of the respondents had received the feminization of poverty reduction support of less than Rp. 2.500.000,00; a total of $8 \%$ of the respondents (KRTP) had received the feminization of poverty reduction support in the fourth week of December 2014; while 92\% of the respondents had received it during the first week in January 2015; $90 \%$ of the respondents stated that the feminization of poverty reduction support 
received had been in accordance with their economic activities and only $10 \%$ of the respondents stated that the support received did not correspond to their economic activities; and a total of $91 \%$ of the respondents (KTRP) stated that the support received had been in accordance with the skills they had and only $9 \%$ of the respondents stated that the support received did not match the skills they had.

In terms of the readiness of female-headed households (KRTP) in administering the feminization of poverty reduction support: a total of $97 \%$ of the respondents (KRTP) stated that they were ready to administer the support while the rest $(3 \%)$ of the respondents said that they were not ready to administer the support; a total of $69 \%$ of the respondents stated that they had administered the feminization of poverty reduction support based on the experience they had; $21 \%$ of the respondents had administered the feminization of poverty reduction support based on their skills; and the rest of the respondents had administered the feminization of poverty reduction support in accordance with the instructions of their accompanying cadres.

In the case of the construction of KRTP's understanding about the meaning of the support provided by the feminization of poverty reduction program: 64\% of the respondents (KRTP) knew that the purpose of the support received as to expand the social network of PKK; whereas, the other $36 \%$ of the respondents did not know the purpose of the provision of the support received; $76 \%$ of the respondents (KRTP) knew that the purpose of the support received as to expand employment opportunities while the other $24 \%$ of the respondents did not know the purpose of the provision of the support received; $82 \%$ of the respondents of very poor households (RTSM) also knew that the purpose of the support received as to motivate KRTP in conducting productive enterprises while $18 \%$ of the respondents did not know the purpose of the support received. 4) In the case of KRTP's commitment to administering the support: total of $92 \%$ of the respondents (KRTP) had committed to administering the support received particularly in the form of a plan to administer the support received in accordance with their experience; whereas, the other $8 \%$ of the respondents did not have plans to administer the support received; 64\% of the respondents (KRTP) had planned to administer the support received in accordance with their experience while the other $26 \%$ of the respondents had planned to administer the support received in accordance with the skills they had.

In terms of social and economic constraints in administering the support: $74 \%$ of the respondents stated that they had no social constraints in administering the support; and as many as $65 \%$ of the respondents (KRTP) stated that the economic constraint they had in administering the support received was particularly in the form of additional capital they had to conduct productive enterprises.

\section{The targeting accuracy of Jalin Matra Assistance}

To specify the targeting accuracy of pilot project the feminization of poverty reduction program Jalin Matra assistance toward Female Heads of Households (KRTP), there were 7 (seven) adopted indicators, namely : 1) The admission of KRTP toward the feminization of poverty reduction program Jalin Matra assistance ; 2) The arrangement of the feminization of poverty reduction program Jalin Matra assistance collected by the KRTP ; 3) The capacity of the feminization of poverty reduction program Jalin Matra assistance collected by the KRTP ; 4) The operating term of the feminization of poverty reduction program Jalin Matra assistance collected by the KRTP ; 5) The conformity between the feminization of poverty reduction program Jalin Matra assistance and the KRTP economic exercise ; 6) The conformity between the feminization of poverty reduction program Jalin Matra assistance and the KRTP competences ; 7) The conformity between the feminization of poverty reduction program Jalin Matra assistance collected and the KRTP poverty stage.

There were 104 KRTP respondents by name and by address. Unfortunately based on the work data there were only $93 \%$ of the respondents who acquired the assistance. It means, there were $7 \%$ of the respondents who didn't obtain the designated assistance. Owing to that reason, this "irrelevance" must be traced. It is suspected that this irrelevant performance has grown bigger especially in "troubled area". During the feminization of poverty reduction program Jalin Matra assistance implementation in the year of 2012 and 2013, The Money team had conducted evaluation studies in Madura and 
regrettably found irrelevant performance in distributing assistance, such as insufficient validity of by name by address data, troublesome place of residence (by address), "unknown name" (by name). Based on the foundings, the assistance administration must be undertaken righteously and be controlled structurally from the province to rural stage.

In addition, there were several unsatisfactory foundings in accordance with the feminization of poverty reduction program Jalin Matra assistance collected by the KRTP, such as the inaccurate list of KRTP respondents and the improper assistance arrangement that "violated" the rules. Based on the statement in Handbook of Jalin Matra Feminization of Poverty Reduction Program Pilot Project, Chapter II, Sub-chapter 7 Budgeting, and figure 4, it states that KRTP assistance is a support for productive economy enterprises. The support consists of investment including business infrastructure and working capital such as raw material and $70 \%$ of business product. Another support is conducted by establishing Karangkitri agricultural movement (Sustainable Food House Region), 30\% of modest livestock and fish farming.

The assistance of the feminization of poverty reduction program should not take the form of welfare money and/or livestock (goat). From the field interview it is known that there were numerous respondents who received welfare money in hands. Escorted by the village mentor, the welfare money must be well spent for "business investment". In the regency of Bojonegoro, all respondents (100\%) received welfare money assistance, furthermore the money was well spent on acquiring productive enterprises infrastructure supervised by the village mentor.

The same scene happened in the regency of Probolinggo. All respondents (100\%) also received welfare money assistance. Those respondents would be given exactly the same inquiry whether they received the assistance in the form of welfare money or other form in hands. Several cases show that the role of Village Mentor is really crucial. Not to mention the feminization of poverty reduction program is viewed as the "female" project since they are members of the Family Welfare Empowerment Movement in rural stage. It had been identified that in a sample village in Bojonegoro regency the activists of the Feminization of Poverty Reduction program were mostly female and it was also simply explained by the Village Chief that those ladies supposed to have control since the project was intended for female.

The data obtained from the field showed $37 \%$ of KRTP respondents received welfare money in cash, while $37 \%$ took the assistance in the form of livestock (goat) and the other $23 \%$ collected business products. However this became a distinctive matter since Jalin Matra program was unlike the Jalin Kesra program especially in regard with the assistance form given to poor households. There were $7 \%$ of KRTP respondents in Pamekasan regency who didn't receive any of the assistance, and later on it was discovered that the society group didn't complete the realization.

Regarding with the amount of assistance received by the KRTP respondents, most of them (73\%) claimed that the assistance amounted to 2.500 .000 Indonesian Rupiahs and it was distributed without any deduction. Sadly, this classic issue in regard with "deduction" is a relentless dilemma since respondents would generally know each other.

The data obtained from the field showed that the assistance were mostly (92\%) given by this week. It means, the assistance dispersion has been overdue from the scheduled or expected time based on the General Handbook. Definitely, the funds transferred to the bank account of the Village Chief should not stay more than 7 (seven) days before it is forwarded or transferred to the Community Group Leader's bank account. Thus, within 5 (five) days the funds must be handed to KRTP respondents. Several data obtained from the field also showed that the time-frame was often violated with inconsiderable reasons, such as the unavailability of respondents' time. Furthermore, from the data it was reported that only several respondents $(8 \%)$ out of all KRTP respondents who claimed that the welfare money was given the previous week. It means, the assistance welfare money was distributed a week after it had been transferred from the province. 
When it comes for the KRTP respondents to answer whether the assistance is relevant to their needs or not, the respondents will provide various answers, since they have different urgencies. Most of the KRTP respondents (94\%) claimed that the assistance received was appropriate and relevant to their needs. Owing to that reason, a concern related to the actual needs of KRTP arises. All of KRTP respondents are the heads of the households and from the survey data it is known that most of KRTP respondents $(53 \%)$ claimed for the need of nine basic staple food (sembako) while the other respondents $(35 \%)$ asserted that they were in need of life quality upgrade. Those 2 (two) necessities are the most essential urgencies among them.

The data obtained from 104 KRTP respondents showed that in almost all regencies equipped with monitoring and evaluation scene the statements in regard with the 2 (two) essential necessities above were the top answers taken from respondents. It seemed there were no significant characteristic when the KRTP respondents were asked whether the assistance was relevant to their economic activities or not. There were $90 \%$ KRTP respondents asserted that the assistance was relevant with their economic activities. Apparently, all regencies share the same statement. There were $100 \%$ of respondents in Pasuruan regency, 70\% in Probolinggo, 100\% in Situbondo, 48\% in Banyuwangi, $75 \%$ in Kediri, $100 \%$ in Ngawi and $65 \%$ in Bojonegoro who claimed that the assistance was relevant with their economic activities.

The data from the field showed that most KRTP respondents (90\%) declared that the assistance given corresponded with their competences and there were only $9 \%$ of the KRTP respondents who claimed that the assistance did not suitable for their competences. The answers related to "the conformity between assistance and competences" were available in almost all regencies that were designated to be the research locations.

\section{The expedience of KRTP in managing Jalin Matra Assistance}

Apparently most of the interviewed KRTP respondents assumed that they were ready to manage the assistance. 97\% respondents claimed that they were prepared to handle the assistance and this data corresponded with all data in all regencies. The readiness of the KRTP respondents in fact varied in managing the assistance. $69 \%$ of the KRTP respondents were ready to handle the assistance based on the experiences that had, while the other $21 \%$ respondents were ready as well and fully capable to manage based on their competences.

Although the data seems to be different, they do not show any significant disparities. Nevertheless, the data is still regarded as outrageous, considering what they had claimed before in regard with their competences and also the percentage of their capabilities in handling the assistance based on the instruction from their companion.

Evidently, there were only $9 \%$ of the respondents who obey the "companion's instruction" in managing the assistance. It is a relatively small percentage. The Feminization Program for Reducing Poverty has had a lot of expectation from the companion personnel as they represent the organization to encourage the development in rural areas. Owing to that reason, the companion personnels have been prepared as the program attendant in province to rural stages.

\section{The KRTP knowledge construction Toward Jalin Matra Assistance}

From the 104 KRTP respondents who had been interviewed, it was reported that there were more respondents (64\%) who actually comprehended the purpose of the Feminization Program for Reducing Poverty than the ones (36\%) who remained uninformed. It is known that only in Pasuruan regency were the higher percentages of the uninformed respondents. Most of the KRTP correspondents identified the purpose of the Feminization Program for Reducing Poverty was to expand job opportunities. Moreover, most of them (82\%) also recognized the other purposes of the Feminization Program for Reducing Poverty, namely to develop the enthusiasm of productive enterprise. Thus it is expected that the respondents develop their enthusiasm in conducting productive enterprise. 
The other purpose of the Feminization Program for Reducing Poverty was to increase their productive enterprise capacity. The KRTP respondents were give quite simplified concept in regard with the purpose of the Feminization Program for Reducing Poverty. Therefore any technical expressions were highly avoided, so that they were able to grasp the purpose thoroughly. However there was still a number of respondents (18\%) who remain uninformed.

\section{The KRTP commitment toward Jalin Matra Assistance Management}

To detect the commitment of the Female Heads of Households (KRTP) in managing the assistance, a simple indicator had been adopted, namely by questioning them whether they had plans to manage the assistance or not. In this circumstance, planning is regarded as essential matter since it holds the character, attitude and decision of what the KRTP must conduct. Thus they will be able to carry out more solid and accurate actions. Even though there were $92 \%$ of KRTP respondents were known to equip themselves with the plans to manage the assistance, still a great concern appeared on the details of their plans.

The KRTP respondents (64\%) had the planning to manage the assistance with their previous life-skill experiences. It seems that "experiences" have become a very important coach for people in rural areas. The experiences include their skills in managing productive enterprise.

\section{The social and economy constraints confronted by the female heads of households (KRTP) in managing Jalin Matra Assistance}

The recent variable used in Monitoring and Evaluation process was the estimation of the success and less-success rate of KRTP assistance management. In other word, KRTP respondents were asked to identify their estimated barriers due to the assistance management. $74 \%$ of the respondents claimed that they didn't bear any social barrier or any other obstacles related to their social relationship. However, due to Jalin Matra assistance management, there are still impediment found, namely the absence of mutual cooperation, society participation, accompaniment and inspirational leader.

Meanwhile, the major impediment encountered by the respondents was the economic matter. They were having lack of investment in conducting their enterprise productively. This matter was experienced by $65 \%$ or more than half of the total respondents in all regencies. This situation is understandable, since a process is required to keep them in productivity thus to eradicate their poverty. Economically the KRRTP respondents had various of barriers, namely the insufficient investment, lack of guidance, passive marketing and lack of staple material.

In accordance with the sustainable program to eradicate poverty designed by East Java Government, the KRTP respondents were questioned on what they suggest toward the poverty eradication program in the following year. 55\% of the respondents asserted that they required business investment. Although there have been different percentages between one regency to another, it indicates that investment is the major problem of "the poor". All of KRTP respondents (100\%) in Situbondo regency recommended the business investment distribution in the following year. While in other regencies, recommendations varied greatly in business investment, productive job opportunity, cash welfare money, or livestock. There were only $2 \%$ of the respondents who demanded basic food staple. It means there have been respectable efforts from the respondents in order to actively struggle without depending on the assistance from the Government.

\section{Conclusion}

This study indicates that the reducing poverty program has met the target. It means that the funds have really been given to the poor female breadwinners, living in the rural areas. The sum of the money has been in agreement with the amount that should be given, and it has been utilized by the target group productively in accordance with the program objectives. 


\section{References}

Ariyani N, Fauzi A, Juanda B \& Beik IS (2015) Evaluasi pogram pengentasan kemiskinan menggunakan metode rappoverty. Jurnal Ekonomi \& Kebijakan Publik 6 (2):181-197.

Ashiomanedu J (2008) Poverty and sustainable development in the Niger delta region of Nigeria. Journal of Sustainable Development in Africa 10 (3):155-171.

Bastos A, Casaca SF, Nunes F \& Pereirinha J (2009) Women and poverty: A gender sensitive approach. The Journal of Socio-Economics 38 (5):764-778.

Brady D \& Kall D (2007) Nearly universal, but somewhat distinct: The feminization of poverty in affluent western democracies, 1969-2000. Social Science Research 37 (3):976-1007.

Cobbinah PB, Black R \& Thwaites R (2013) Dynamics of poverty in developing countries: Review of poverty reduction approaches. Journal of Sustainable Development 6 (9):25-35.

Domfeh KA \& Bawole JN (2009) Localizing and sustaining poverty reduction: Experiences from Ghana. International Journal of Management of Environmental Quality 20 (5):490-505.

Fosu AK (2017) Growth, inequality, and poverty reduction in developing countries: Recent global evidence. Research in Economics 71 (2):306-336.

Goswami R \& Majundar S (2016) Construction of gender sensitive poverty line based on local perception: Evidence from Habra-II Block of West Bengal state in India. The Social Science Journal 54 (1):76-92.

Husna DN (2018) Efektifitas program Jalin Matra terhadap kesejahteraan janda miskin di Desa Sumberjo Kecamatan Sanankulon Kabupaten Blitar ditinjau dari ekonomi Islam. Martabat: Jurnal Perempuan dan Anak 2 (2):202-2018.

Jackson C (1998) Woman and poverty or gender and well-being? Journal of International Affairs 52 (1):67-81.

Klasen S, Lechtenfeld T \& Povel F (2013) A feminization of vulnerability? Female headship, poverty, and vulnerability in Thailand and Vietnam. World Development 71:36-53.

Kurniawan YT (2018) Strategi optimalisasi program penanggulanagan kerentanan kemiskinan (Studi kasus program Jalin Matra PK2 di Desa Ngroto Kecamatan Pujon Kabupaten Malang. Cakrawala $12(1): 95-105$.

Mahsunah D (2013) Analisis pengaruh jumlah penduduk, pendidikan dan pengangguran terhadap kemiskinan di Jawa Timur. Jurnal Pendidikan Ekonomi 1 (3):1-17.

Mederios M \& Costa J (2008) Is there a feminization of poverty in Latin America? World Development 36 (1):115-127.

Mufidah S (2018) Implementasi Program Jalan Lain Menuju Mandiri dan Sejahtera (Jalin Matra) dalam Penanggulangan Kerentanan Kemiskinan (PK2) di Desa Domas Kecamatan Menganti Kabupaten Gresik. Theses: Universitas Airlangga Surabaya.

Nurmawati Y \& Soseco T (2017) The effectiveness of Jalin Matra Penangulanan Kerentanan Kemiskinan Programme in Village of Ngroto. Jurnal Ekonomi dan Studi Pembangunan 9 (2):167-175.

Pearce D (1978) The feminization of poverty: Woman work and welfare. Urban and Social Review 11:28-36.

Perdana AA \& Maxwell J (2004) Poverty Targeting in Indonesia: Programs, Problems and Lessons Learned. Dalam: Centre for Strategic and International Studies Economic Working Paper Series, Jakarta, Indonesia.

Pressman S (2003) Feminist explanations for the feminization of poverty. Journal of Economic Issues 36 (2):353-361.

Singgih DS \& Sudarso (2013) Evaluasi Pelaksanaan Program Jalin Kesra Bantuan RTSM Provinsi Jawa Timur. Surabaya: Kerjasama antara Badan Pemberdayaan Masyarakat Provinsi Jawa Timur dengan Lembaga Penelitian dan Pengabdian pada Masyarakat Universitas Airlangga.

Singgih DS, Sudarso \& Mas'udah S (2020) The use of mixed methods to identify typology of poverty in East Java, Indonesia. Jurnal Sosiologi Dialektika 15 (1):9-15.

Tain A (2011) Penyebab kemiskinan rumah tangga nelayan di wilayah tangkap lebih Jawa Timur. Humanity 7 (1):1-10.

Tarkowska E (2002) Intra-household gender inequality: Hidden dimensions of poverty among Polish women. Communist and Post-Communist Studies 35 (4):411-432. 
Zamhari J, Wisadirana D \& Kanto S (2015) Analisis determinan kemiskinan di Jawa Timur. Wacana 18 (1):41-50.

Zarkasi (2015) Pedoman Umum Pilot Project Jalin Matra Penanggulangan Kerentanan Kemiskinan. Surabaya: Badan Pemberdayaan Masyarakat. 